\title{
An Unexpected Cause of Diffuse Alveolar
Hemorrhage in an Immunocompetent Young Patient: Herpes Simplex Type 1 Related Pneumonia
}

\author{
Immunitesi Sağlam Genç Bir Hastada Beklenmedik Sebebe Bağlı Diffüz \\ Alveoler Hemoraji; Herpes Simplex Tip-1 ilişkili Pnömoni
}

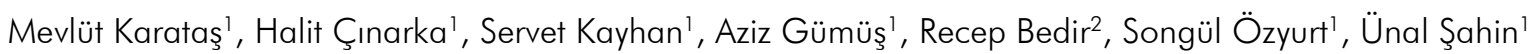

\begin{abstract}
An 18-year-old man was admitted to the hospital with the complaints of dyspnea, cough and hemoptysis. The physical examination revealed, herpes labials on the lower lip and crackles in the middle and lower regions of both lungs. Laboratory tests revealed a leukocyt count of $21.700 / \mathrm{mm}^{3}$, hemoglobulin level of $6.80 \mathrm{~g} / \mathrm{dL}$, hematocrit of $23.2 \%$, CRP of 5.46 $\mathrm{mg} / \mathrm{dl}$, and HSV-l lgM was positive. The thorax CT revealed bilateral and diffuse ground glass appearance and interlobuler septal thickening on both pulmonary paranchymal areas. Active bleeding was observed in the entire tracheobronchial system by bronchoscopy. Microscopic images showed hemosiderin-loaded macrophages. We diagnosed HSV-1 related pneumonia and diffuse alveolar hemorrhage (DAH). We treated the patient with acyclovir, corticosteroid, erythrocyte suspension, cryoprecipitate, and tranexamic acid. The patient improved dramatically. Finally, while HSV-1 related pneumonia is usually seen in immunocompromised hosts and critically ill patients, in the present case, a healthy immunocompetent man was infected with HSV-1. Following medication, the patient was completely healed. We think that the current case is a rare disease of HSV-1 leading to DAH.
\end{abstract}

Key words: Herpes simplex virus, pneumonia, diffuse alveolar hemorrhage.

\section{Özet}

On sekiz yaşında erkek hasta nefes darlığı, öksürük, kanlı balgam şikâyetiyle hastanemize başvurdu. Fizik bakıda vital bulguları normaldi. Alt dudakta herpes labialis ve akciğerler orta-alt bölgede inspiratuar raller mevcuttu. Laboratuvarında lökosit $21.700 / \mathrm{mm}^{3}$, hemoglobin $6,80 \mathrm{~g} / \mathrm{dL}$, hematokrit \%23,2, CRP 5,46mg/dl ve viral panelinde HSV-1 IgM pozitiffi. Toraks $\mathrm{BT}^{\prime}$ de her iki akciğerde diffüz buzlu cam opasitesi, interlobuler septal kalınlaşmalar görülmekteydi. Fiberoptik bronkoskopide trakeobronşial sistemde diffüz eritem ve kanama saptandı. Bronkoalveoler lavajda hemosiderin yüklü makrofajlar görüldü. HSV-1'e bağlı pnömoni ve diffüz alveoler hemoraji (DAH) düşünülen hastaya acyclovir, kortikosteroid, eritrosit süspansiyonu, taze donmuş plazma ve tranexamik asit başlandı. Tedaviye dramatik cevap gelişti. Sonuç olarak, HSV-1 pnömonisinin sıklıkla immün suprese ve yoğun bakım hastalarında görüldüğü bilinmesine karşın olgumuzda immünitesi normal, genç bir hastada HSV-7'e bağlı pnömoni ve DAH kliniğinin geliştiğini görmekteyiz. Bu olgunun HSV-1'e bağlı gelişen, DAH patolojisiyle seyreden ve seyrek görülen bir olgu olduğu kanısındayız.

Anahtar Sözcükler: Herpes simplex virus, pnömoni, diffüz alveoler hemoraji.

\footnotetext{
'Department of Pulmonology, Recep Tayyip Erdoğan University Faculty of Medicine, Rize, Turkey

${ }^{2}$ Department of Pathology, Recep Tayyip Erdoğan University Faculty of Medicine, Rize, Turkey

'Recep Tayyip Erdoğan Üniversitesi Tıp Fakültesi, Göğüs

Hastalıkları Anabilim Dalı, Rize

${ }^{2}$ Recep Tayyip Erdoğan Üniversitesi Tıp Fakültesi Patoloji Anabilim Dalı, Rize
}

Correspondence (iletişim): Mevlüt Karataş, Department of Pulmonology, Recep Tayyip Erdoğan University Faculty of Medicine, Rize, Turkey

e-mail: fmkaratas@yahoo.com 
A variety of pulmonary pathologies may cause diffuse alveolar hemorrhage (DAH) which is a life-threatening clinical entity and requires urgent treatment. DAH often results in acute respiratory failure that requires early diagnosis and aggressive treatment. The diagnosis of DAH is difficult. DAH originates from the pulmonary microvasculature and responsible to alveolar damage. There are many conditions that can cause DAH. Most etiologies share a common pathophysiologic theme: damage to the alveolar microcirculation; any source of injury to the alveolar microcirculation can cause alveolar hemorrhage. Most patients present with dyspnea, cough, hemoptysis, and new alveolar infiltrates on chest imaging. Autoimmune disorders are the most frequent cause of DAH (1). Pulmonary infections can also cause DAH. HSV-1 causes a variety of infections that involve the upper and lower air way. HSV-1 related pneumonia showed especially in immunocompromised patients. We report a case of community acquired pneumonia related to Herpes simplex type 1 virus (HSV-1) presented with a clinical table of diffuse alveolar hemorrhage.

\section{CASE}

An 18-year-old-young man was admitted to our emergency department with the complaints of cough, episodic bloody sputum, fatigue, and progressive dyspnea for two days. The patient was a non-smoker and there was no specific disease in his medical history. The physical examination revealed a $37.2{ }^{\circ} \mathrm{C}$ fever, oxygen saturation on room air of $86 \%$, heart rate of $138 / \mathrm{min}$, respiratory rate of 14 breaths/min, herpes labialis on the lower lip, and crackles in middle and lower regions of both lungs. Laboratory tests revealed a white blood cell count of $21.700 / \mathrm{mm}^{3}$ with neutrophilic predominance and lymphopenia, hemoglobin level of $6.80 \mathrm{~g} / \mathrm{dL}$, hematocrit of $23.2 \%$, platelet count of $172.000 \mathrm{~K} / \mathrm{uL}$, serum creatinine level of $0.58 \mathrm{mg} / \mathrm{dL}, \mathrm{LDH}$ of $500 \mathrm{U} / \mathrm{L}$, troponin level of $0.08 \mathrm{ng} / \mathrm{ml}$, erythrocyte sedimentation rate of $16 \mathrm{~mm} /$ hour, and urine analysis was normal. The coagulation study revealed a mildly elevated prothrombin time of $17.9 \mathrm{sec}$. and partial thromboplastin time of $30.8 \mathrm{sec}$. The rheumatologic workup, including all of the antinuclear antibodies, anti-double stranded antibodies, antineutrophil cytoplasmic antibodies, and anti-glomerular basement membrane antibodies were negative. Serological tests were as follows: C-reactive protein: $5.46 \mathrm{mg} / \mathrm{dl}$, rheumatoid factor: less than $20 \mathrm{IU} / \mathrm{mL}$, and the brucella test was negative. ELISA tests, including $\mathrm{HBsAg}$, anti-HBs, anti-HCV, anti-HIV, anti-toxo $\lg M$, anti-CMV IgM, EBV
VCA IgM, Herpes simplex type $2 \lg G$, and Herpes simplex type $2 \lg M$ were negative. Anti-toxo lgG, anti-CMV $\lg$, EBV EBNA lgG, HSV-1 $\lg M$ and HSV-1 lgG were positive. There were no bacteria in the sputum culture. The chest $x$-ray revealed bilateral alveolar infiltrations (Figure 1). The computed tomography revealed diffuse ground-glass opacities and interlobular septal thickening on both pulmonary parenchymal areas (Figure 2). Diffuse erythema and bleeding were observed by fiberoptic bronchoscopy in the tracheobronchial system (Figure 3). Bronchoalveolar lavage of the left lower lobe showed progressively bloody return, consistent with alveolar hemorrhage. The microbiologic and cytological examination revealed no evidence of infection or malignancy. There were no bacteria in the bronchoalveolar lavage culture. Microscopic images of bronchoalveolar lavage showed hemosiderin loaded macrophages and inflammatory cells ( $F$ igure 4). All of the radiologic and laboratory results were consistent with the diagnosis of HSV-1 related pneumonia Therefore, we administered medical treatment with intravenous administrations of acyclovir (500 mg 2x1), high dose corticosteroid (methylprednisolone, $120 \mathrm{mg}$ ), erythrocyte suspension, cryoprecipitate, and tranexamic acid (250 mg, 4x1) to prevent bleeding from the endobronchial system. The patient responded to medical therapy. Clinical and biochemical parameters of the patient improved dramatically. During the medical follow up period, there was no fever, dyspnea, or bloody sputum. Pulmonary function and radiologic findings gradually recovered. After eleven days of treatment, control chest $x$-ray, and computed tomography were shown as healing images in the pulmonary parenchymal areas.

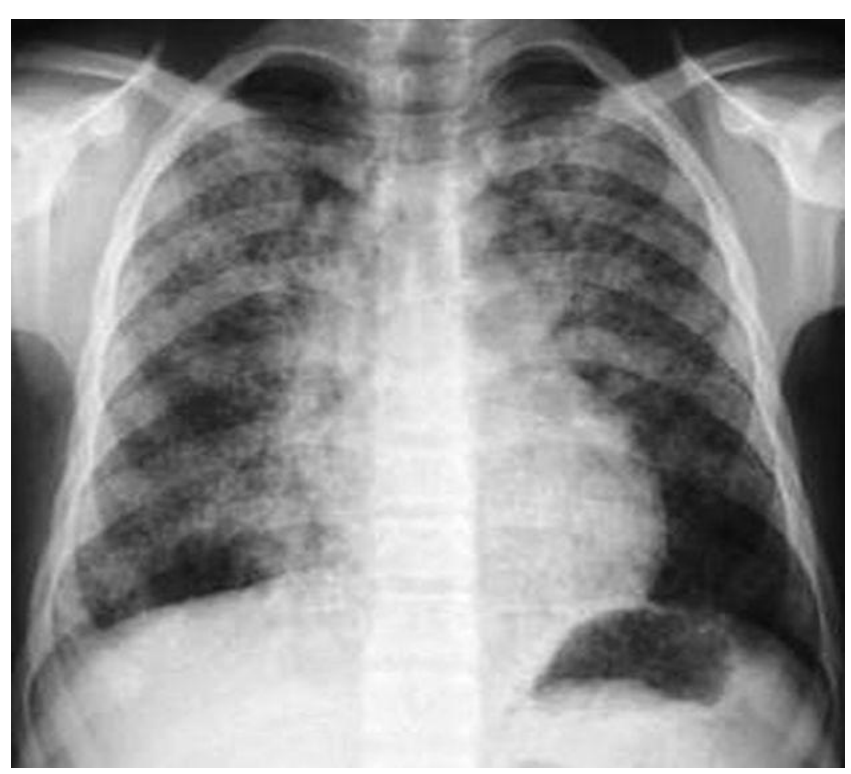

Figure 1: Initial chest $x$-ray showed bilateral alveolar infiltrates 


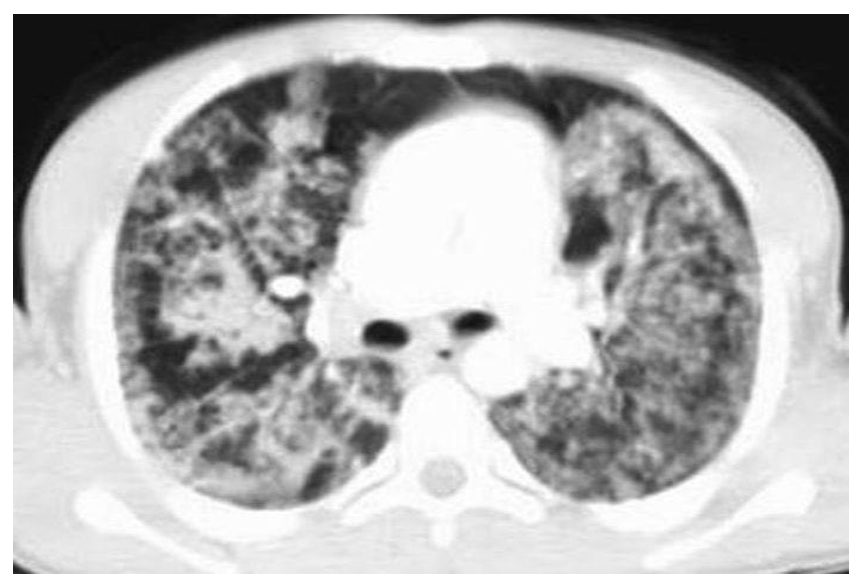

Figure 2: Thoracic computed tomography showed bilateral, diffuse ground glass opacities and interlobular septal thickening

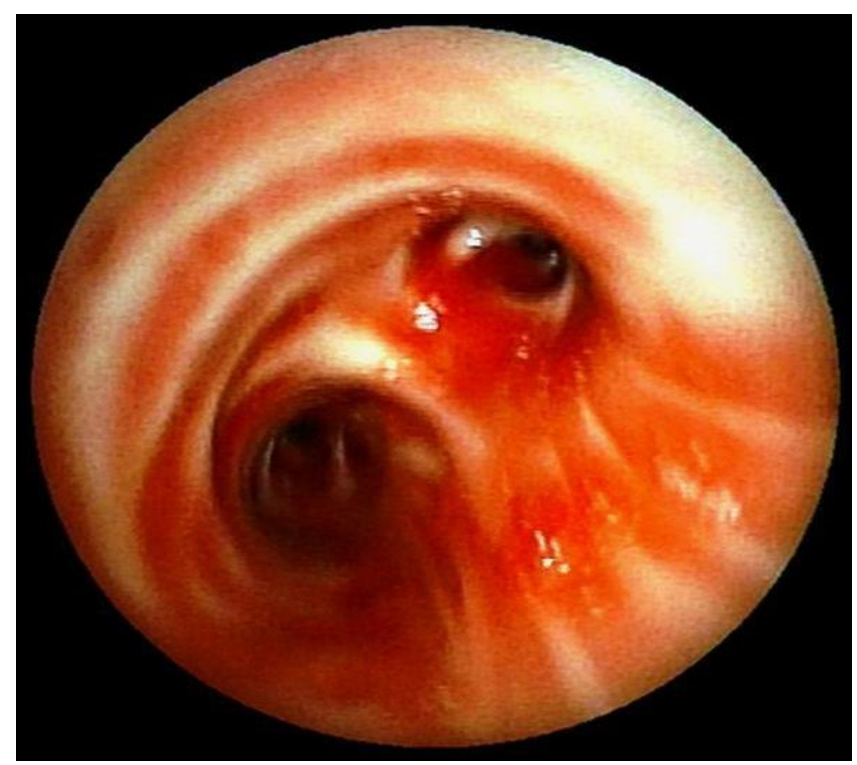

Figure 3: Fiberoptic bronchoscopy revealed diffuse airway erythema and bleeding

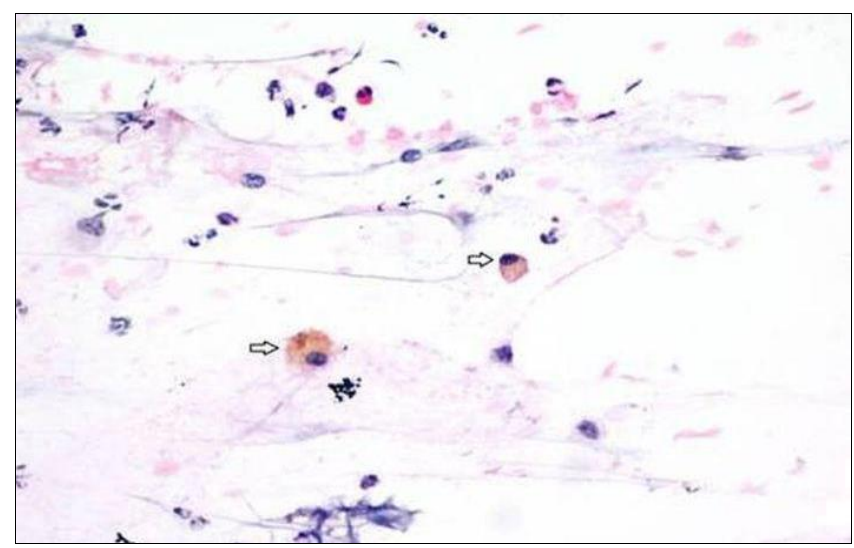

Figure 4: Inflammatory cells, respiratory tract epithelial cells and hemosiderin loaded macrophages (black arrow) were observed in the cytological examination of the bronchial lavage obtained by bronchoscopy (H\&Ex440)

\section{DISCUSSION}

Diffuse alveolar hemorrhage (DAH) is a life-threatening condition caused by a diverse group of disorders. DAH originates from the pulmonary microcirculation including alveolar capillaries, arterioles, and venules. The underlying disease mechanism may be either pulmonary specific (e.g.: diffuse alveolar damage, or infections) or more generalized (vasculitis) (1).

Herpes simplex infections are very common in the human population. HSV-1 causes a variety of infections that involve mucocutaneous surfaces, the central nervous system, and occasionally visceral organs such as the lungs $(2,3)$. HSV-2 mostly causes Herpes genitalis, and at the same time may be recognized in $10 \%$ to $20 \%$ of cases in Herpes labialis (4). Primary HSV infections are seen usually in the upper respiratory system as gingivostomatitis or pharyngitis. Some viruses of the herpes virus family, such as HSV (e.g.: types 1, 2, 6, and 8), Varicella zoster, and CMV can cause pneumonia (5).

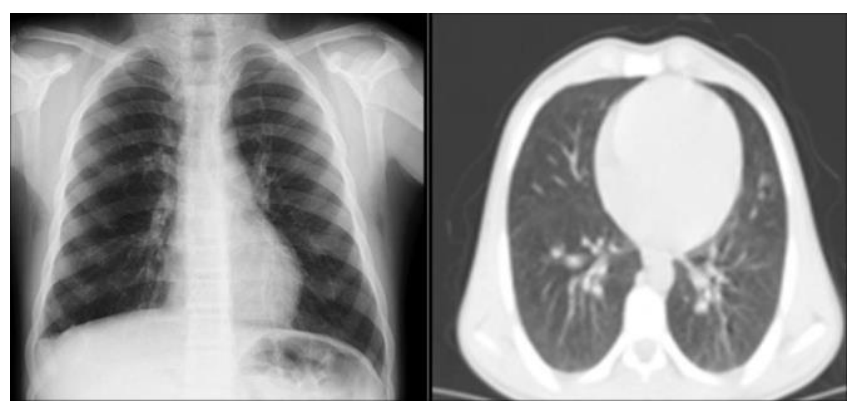

Figure 5: Fiberoptic bronchoscopy revealed diffuse airway erythema and bleeding

Herpes simplex virus-related pneumonia is primarily caused by HSV- 1 and rarely caused by HSV-2 $(6,7)$. Humoral and cell-mediated immunity act in response to HSV-1 infections. The most severe HSV-1 disease occurs in immunocompromised host (e.g.: the elderly; bone marrow transplant recipients; or patients with severe pulmonary disease or Human immunodeficiency virus infections); and critically ill patients $(8,9)$. Published reports of HSV pneumonia are based on autopsy cases because of false diagnosis and high mortality among untreated patients (10).

The herpes simplex virus may reach the lungs through three different means. The contiguous spread to the lower respiratory tract, aspiration of HSV, or oropharyngeal lesions may play a role in many cases (11). Pathologically, HSV infection can have three main forms of pulmonary involvement: necrotizing tracheobronchitis, necrotizing pneumonia, and interstitial pneumonitis (12). The interstitial pneumonitis form of HSV pulmonary infection is characterized by diffuse alveolar damage consisting of interstitial lymphocytic infiltration, alveolar hemorrhage, and hyaline membrane formation (13). Computed tomogra- 
phy findings of HSV pneumonia are diffuse or multifocal ground glass attenuation, peribronchial consolidation, or a mixed pattern of both findings $(6,7)$.

In our case, sputum and bronchoalveolar lavage cultures were negative for microbilogical growth. HSV- $1 \lg M$ and HSV-1 lgG were positive in the ELISA tests. Additionally, the physical examination of the patients revealed Herpes labialis on the lower lip. Computed tomography findings were compatible with HSV-1 related pneumonia. Although many conditions can cause DAH, all diagnostic steps were taken to diagnose HSV-1 related pneumonia and resulted diffuse alveolar hemorrhage. Antiviral treatment was administered and radiological and clinical healing were dramatically observed.

As conclusion; In this case, an 18-year-old healthy young man was infected by HSV-1, which resulted in serious pneumonia and diffuse alveolar hemorrhage. While some published papers showed that HSV-1 infection can usually cause pneumonia in immunocompromised hosts and critically ill patients, in the present case, a healthy/immunocompetent man was infected by HSV-1, which resulted in diffuse alveolar hemorrhage. After taking antiviral medication, the patient completely covered, as revealed in both the chest $\mathrm{x}$-ray and computing tomography images (Figure 5). We believe that the current case is a rare disease of HSV-1 leading to DAH.

\section{CONFLICTS OF INTEREST}

None declared.

\section{AUTHOR CONTRIBUTIONS}

Concept - M.K., A.G., R.B., H.Ç., Ü.Ş., S.K., S.Ö.; Planning and Design - M.K., S.K., S.Ö., A.G., H.Ç., Ü.Ş., R.B.; Supervision - M.K., A.G., R.B., H.Ç., Ü.S.., S.K., S.Ö.; Funding - M.K., R.B., Ü.S..; Materials - M.K., S.K., R.B.; Data Collection and/or Processing - M.K., R.B.; Analysis and/or Interpretation - M.K., S.K., H.Ç.; Literature Review - M.K., S.Ö.; Writing - M.K.; Critical Review Ü.Ş., S.Ö.

\section{YAZAR KATKILARI}

Fikir - M.K., A.G., R.B., H.Ç., Ü.Ş., S.K., S.Ö.; Tasarım ve Dizayn - M.K., S.K., S.Ö., A.G., H.Ç., Ü.Ş., R.B.; Denetleme - M.K., A.G., R.B., H.Ç., Ü.Ş., S.K., S.Ö.; Kaynaklar - M.K., R.B., Ü.S.; Malzemeler - M.K., S.K., R.B.; Veri Toplama ve/veya İsleme - M.K., R.B.; Analiz ve/veya Yorum - M.K., S.K., H.Ç.; Literatür Taraması - M.K., S.Ö.; Yazıyı Yazan - M.K.; Eleştirel İnceleme - Ü.Ş., S.Ö.

\section{REFERENCES}

1. Collard HR,Schwarz MI. Diffuse alveolar hemorrhage. Clin Chest Med 2004; 25:583-92. [CrossRef]

2. Corey L. Herpes simplex virus. In: Mandell GL, Bennett JE, Dolin $R$, eds, Principles and practice of infectious diseases, 5th ed. Philadelphia, PA: Churchill Livingstone, 2000; 1564-80.

3. Whitley RJ, Roitzman B. Herpes simplex viruses. In: Richman DD, Whitley RJ, Hayden FG, eds, Clinical virology, 2nd edn. Washington, DC: ASM Press, 2002; 375-401.

4. Feldman S, Stokes DC. Varicella zoster and herpes simplex virus pneumonias. Semin Respir Infect 1987; 2:8494.

5. Miyazato A, Kishimoto H, Tamaki K, Nakama K, Saito A. Herpes simplex bronchopneumonia in a nonimmunocompromized individual. Intern Med 2001; 49:836-40.

6. Aquino SL, Dunagan DP, Chiles C, Haponik EF. Herpes simplex virus 1 pneumonia: patterns on CT scans and conventional chest radiographs. J Comput Assist Tomogr 1998; 22:795-800. [CrossRef]

7. Gasparetto EL, Escuissato DL, Inove C, Marchiori E, Müller NL. Herpes simplex virus type 2 pneumonia after bone marrow transplantation: high-resolution CT findings in 3 patients. J Thorac Imaging 2005; 20:71-3.

8. Corey L, Spear PG. Infections with herpes simplex viruses (1). N Engl J Med 1986; 314:686-91. [CrossRef]

9. Wilton JM, Ivanyi L, Lehner T. Cell-mediated immunity in Herpesvirus hominis infections. Br Med J 1972; 1: 723-6. [CrossRef]

10. Martinez E, de Diego A, Paradis A, Perpiñá M, Hernandez M. Herpes simplex pneumonia in a young immunocompetent man. Eur Respir J 1994; 7:1 185-8.

11. Nash G. Necrotizing tracheobronchitis and bronchopneumonia consistent with herpetic infection. Hum Pathol 1972; 3:283-91. [CrossRef]

12. Travis WD, Colby TV, Koss MN, Rosado-de Christenson, ML, Muller NL, King TE. Non-neoplastic disorders of the lower respiratory tract. Washington DC, USA: American Registry of Pathology, 2002.

13. Ramsey PG, Fife KH, Hackman RC, Meyers JD, Corey L. Herpes simplex virus pneumonia: clinical, virologic, and pathologic features in 20 patients. Ann Intern Med 1982; 97:813-20. [CrossRef] 